УДК 94. 477.340. 15

Прокіп А. В.,

andrprokip@gmail.com,ORCID ID: 0000-0002-7941-9909,

Researcher ID AAE-9107-2019,

к.і.н., дои., провідний науковий співробітник,

Львівський історичний музей, м. Львів

Михальський Ю. В.,

myhalski@gmail.com,ORCID ID: 0000-0002-1564-2604,

Researcher ID F-1372-2019,

к.і.н., дои., завідувач кафедри історії і філософії,

Львівський торговельно-економічний університет, м. Львів

\title{
ТРИ СУДОВІ ПРОЦЕСИ ПЕТРА БУБЕЛИ
}

Анотація. Метою даної статті є розкриття юридичних колізій на життєвому шляху Петра Бубели (трьох судових процесів за його участі - 1911, 1919 та 1931 рр.) - одного з провідних галицьких військових діячів, юриста за освітою, який упродовж 1908-1913 рр. навчався на правничому факультеті Львівського університету. Методологія дослідження спирається на принципи історизму, об'єктивності та системності. У ході дослідження застосовувалися такі конкретно-історичні методи: проблемно-хронологічний та історико-біографічний. Наукова новизна полягає в тому, що на основі опублікованих та неопублікованих джерел (архівних документів) і наукових розвідок розглянуто причини, хід, наслідки трьох судових прочесів, у яких доводилося брати участь П. Бубелі в різних якостях. На судовому процесі 1911 р. П. Бубела виступав як обвинувачуваний австрійською владою нібито в образі релігійних почуттів селян на зборах громади села Лисиничі, що відбулися 1910 р. На судовому проиесі 1911 р. П. Бубелу засуджено до двох тижнів арешту, замінених згодом грошовим штрафом.

У період Західноукраїнської Народної Республіки (ЗУНР) П. Бубела входив до складу галицького уряду, займав посаду заступника державного секретаря військових справ. У 1919 р. взяв участь як військовий юрист і представник влади в судовому проиесі над генералом М. Тарнавським.

31920 р. проживав в Одесі. На початку 1931 р. заарештований радянськими органами Державного політичного управління (ДПУ) й звинувачений в антирадянській діяльності, зокрема в участі та керівництві військовою групою т. зв. «української контрреволюиійної організаиї̈, щџо нібито діяла на Одещині, була частиною «Всеукраїнського начіонального центру» на чолі з М. Грушевським і Г. Коссаком та нібито готувала збройне повстання проти радянської влади, в членстві та керівництві одеським відділенням Украӥнської Військової Організаиї (УВО). Після закритого судового розгляду «судова трійка» ДПУ засудила П. Бубелу до трьох років таборів. Реабілітований посмертно в 1989 р.

Ключові слова: П. Бубела, судовий процес, судова «трійка», Одеса, радянський режим, Державне політичне управління (ДПУ), Українська військова організація (УВО).

Prokip A. V.,

andrprokip@gmail.com,ORCID ID:0000-0002-7941-9909,

ResearcherID AAE-9107-2019,

Ph.D. in History, Associate Professor, Leading Researcher,

Lviv Historical Museum, Lviv

Mykhalskyj Yu. V.,

myhalski@gmail.com,ORCID ID: 0000-0002-1564-2604,

ResearcherID F-1372-2019,

Ph.D. in History, Associate Professor, Head of the Department of History and Philosophy,

Lviv University of Trade and Economics, Lviv 


\section{THREE TRIALS OF PETRO BUBELA}

Abstract. The purpose of this article is to reveal the legal conflicts in the life of Peter Bubela (three trials with his participation - 1911, 1919 and 1931) - one of the leading Galician military figures, a lawyer by education, who during 1908-1913 studied law Faculty of Lviv University. The research methodology is based on the principles of historicism, objectivity and systematics. The following specific historical methods were used in the study: problem-chronological and historical-biographical. The scientific novelty lies in the fact that on the basis of published and unpublished sources (archival documents) and scientific investigations the causes, course, consequences of three lawsuits in which P. Bubeli had to participate in different capacities are considered. At the trial in 1911, P. Bubela acted as an accused by the Austrian authorities in the image of the religious feelings of the peasants at a meeting of the community of the village of Lysynychi, which took place in 1910. At the trial in 1911, P. Bubela was sentenced to two weeks in prison. subsequently a fine.

During the period of the Western Ukrainian People's Republic (WUPR-ZUNR) P. Bubela was a member of the Galician government, held the position of Deputy Secretary of State for Military Affairs. In 1919 he took part as a military lawyer and a representative of the authorities in the trial of General M. Tarnavsky.

From 1920 he lived in Odesa. In 1931 he was arrested by the Soviet bodies of the State Political Administration (SPA-DPU) and accused of anti-Soviet activities, in particular of participating in and leading a so-called military group. The "Ukrainian counter-revolutionary organization" that allegedly operated in the Odesa region was part of the All-Ukrainian National Center, led by M. Hrushevsky and G. Kossak, and was preparing an armed uprising against Soviet rule, membership and leadership of the Odesa branch of the Ukrainian Military Organization (UMO-UVO). After a closed trial, the DPU's "judicial trijka" sentenced P. Bubela to three years in prison camps. Rehabilitated posthumously in 1989.

Key words: P. Bubela, trial, "trijka" trial, Odesa, Soviet regime, State Political Administration (DPU), Ukrainian Military Organization (UMO-UVO).

\section{JEL: K 41}

\section{DOI: 10.36477/2616-7611-2021-10-02}

Постановка проблеми. Петро Бубела - юрист за освітою, український військовий, державний і громадсько-політичний діяч першої половини $\mathrm{XX}$ ст., який усе життя присвятив боротьбі за права українського народу, походив із селянської родини. Його батько, Іван Бубела із села Лисиничі, не маючи можливості дати вищу освіту всім своїм дітям, а їх у нього було шестеро, вирішив дати освіту Петру.

Як згадував П. Бубела: «Народився у 1889 році в сім'їселянина. Крім мене, було 3 братів 3 сестри. Вчився я один. Закінчив академічну українську гімназію у Львові в 1908 р. Цього ж року записався до юридичного факультету Львівського університету» [3, арк. 3]. Зокрема, згідно з документами деканату юридичного факультету, студент П. Бубела в 1908/1909 н. р. вивчав такі предмети, як «Історія і система німецького права», «Католицьке церковне право», «Історія устрою Австрії» та ін. [2, арк. 215].

Аналіз останніх досліджень і публікацій. Для написання статті було використано спогади безпосередніх учасників подій, таких як I. Боберський [1] і М. Тарнавський [11]. Праці дослідників К. Курилишина [5], В. Кучерука [6], М. Литвина, К. Науменка [8; 9], В. Лаби [7],
Г. Палажій [10] частково відображають дану проблематику. Джерельною базою послужили матеріали Центрального державного історичного архіву України в м. Львові [12], Державного архіву Львівської області [2], Державного архіву Одеської області [3].

Постановка завдання. Метою публікації $є$ розгляд юридичних колізій на життєвому шляху Петра Бубели, пов'язаних із трьома судовими процесами за його участі 1911, 1919 та 1931 pp.

Виклад основного матеріалу дослідження. Ще будучи студентом юридичного факультету, П. Бубела включився в активну громадську та політичну роботу, в якій йому діяльно допомагав товариш, колега по гімназії та правничому факультету, майбутній військовий та політичний лідер Євген Коновалець. П. Бубела зазначав, що «у гімназії до жодної партії не належав, правда, брав участь у позашкільних гуртках, гуртки ці більш політичного виразного характеру не носили. На університеті, як і вся тоді студентська молодь, брав участь у культурно-освітній роботі серед селянства. Роботу переважно проводило студентство, особливо діти селян, які пожадали принести користь тому суспільству, з якого вони вийшли...» [3, арк. 3]. 
Ця робота не всім подобалася, і 1911 р. йому вперше довелося зіткнутися з репресивною системою держави, тоді Австро-Угорської імпеpiï. Справа полягала в нібито образі релігійних почуттів віруючих, якої П. Бубела припустився на селянських зборах громади Лисинич 1910 р.

Судовий процес над П. Бубелою висвітлювався в тодішній пресі, зокрема в часописі «Діло», де 3 цього приводу можна прочитати таке: «Вчера відбувалася перед львівським карним трибуналом розправа проти студ. прав Петра Бубели з Лисинич під Львовом обжалуваного о обиду релігії за параграф 303 3. К. Вини допустився обжалуваний в той спосіб, що дня 22 грудня м. p. перед зібраними селянами Лисинич відчитав фейлетон М. Курцеби п. 3. «Шкрипция», поміщений у «Свободі» 315 грудня 1910. Фейлетон відносився до справи конскрипції і мав на меті виказати, що руські селяни-латинники є Русинами. М. и. у фейлетоні подано «Отче наш», так як його говорять латинники, не знаючи польської мови і намагаючі говорити молитву польською мовою. За відчитанє сего фейлетону потягнено п. Бубелу до судово-карної одвічальности. Під час розправи зізнали всі сьвідки, що Бубела не ніякої обиди релігії не допускався. Коли підчас читаня хтось в куті засьміявся, читаючий перший звернув йому увагу, що нема чого сьміятися, бо він відчитує статю не для жартів і кпин, але дає доказ, як перекручує навіть молитву «Отче наш» такий Русин, що не вміє, а хоче говорити по польськи. I власне $з$ того декотрі сьвідки - як пр. сьв. Кость Баран - сьміялися, але не 3 самої молитви. Закинено також обжалованому, що не обмежився на відчитаню інкримінованого «Отченашу», але додавав від себе обиджаючі релігію «пояснення». Обжалуваний заперечував се, а оборонець др. Михайло Терлецький вносив так в слідстві як на розправі на переслуханє сьвідків, що весь час стояли близько обжалуваного, а ніяких таких слів не чули. Одначе слідчий судия, а так само і трибунал не допустили сих сьвідків, тільки оперлися на сьвідках, що стояли коло дверий і з надвору та 3 природи річи серед розмов і гамору не могли поодиноких слів бесідника чути. Двох сьвідків, Марию Бачинську і Павлину Баран на внесенє прокуратора відіслано до слідчої вязниці за те, що при розправі зложили иньші зізнання, як в слідстві вони потверджували, що чули такі і такі слова. Заприсяжені мусіли відкликати сі зізнаня, заявляючи, що під присягою не можуть говорити неправди. Тепер будуть за те відповідати. Трибунал по переведеній розправі засудив об жалуваного на 14 днів арешту. Проти засуду оборона внесла відклик до касаційного трибуналу» $[4$, с. 3$]$.

3 великими труднощами П. Бубелі вдалося тоді уникнути реального ув'язнення, заміненого грошовим штрафом. Він сам зазначав: «...Львівський суд без фактичних даних присудив мене на 2 тижні в'язниці за образу релігії, що потягло за собою за тодішніми законами втрату студентських прав. 3 великими труднощами, ухвала суду, себ-то в'язниці була замінена грошовою карою, i це дозволило продовжувати студії і роботу. Але ж мені відплачено другим, а саме забрано на військову службу в момент, коли скінчав Університет і повинен був приступити до іспиту, а тим самим цілковито ізольовано від політичного життя. Випадків такого поводження було не мало, оскільки після 1908 року (вбивство намісника графа Потоцького студентом Січинським) національна боротьба між українцями i поляками дуже загострилась. Вказати належить про обставини, серед яких українцям приходилось в ті часи жити, впливати на виховання молоді, на уклад іiі світогляду і тому більшість іiі була напрямку націоналістичного, себе не виключаю. В той час ми не знали і не відчували боротьби партій, ми й не дуже тим цікавились. Я був у тій частині студентства, яка йшла працювати на село - провадила там різні кампанії як: вибори до сойму, парламенту, агітуючи за всіх, хто йшов проти польського панування над українцями, під австрійською егідою, перепису людности, тощо, а крім цього проводили організацію окремих інституцій» [3, арк. 3].

Не завершивши до кінця своє навчання на юридичному факультеті, П. Бубела був змушений піти до армії на однорічну службу як «добровільний охотник» у 1913 р. Початок Першої світової війни затягнув його однорічну військову службу на кілька років. У час війни П. Бубела став фаховим військовим, брав участь у боях під Перемишлем, де в листопаді 1914 р. був важко поранений, воював на італійському фронті. Закінчивши старшинські курси, отримав звання оберлейтенанта, згодом майора. Про події Першої світової війни П. Бубела згадував так: «мене відряджено на фронт як звичайного салдата, через що мені прийшлось багато страдати як морально, так і фізично. Я не хочу тут сказати, що мені дуже хотілось бути офіцером. Я добре розумів це, що чини офіцерські дають таким як я тільки тому, щоби спасати від позицій панських дітей. Алеж водночас я бачив, що ставши офіцером, я зможу 
хоч частково в ті тяжкі хвилини допомогти сірій масі салдатів, які самі сиділи на фронті, а батьків їх гнали в тюрми, або вішали на вербах, мовляв за прихильність до москалів» [3, арк. 4].

У 1918 р. його військові здібності вирішила використати українська національна рада, члени якої, розуміючи, що Австро-Угорщина доживає останні дні, почали розмірковувати над тим, як, випередивши поляків, взяти владу над Львовом та Галичиною. П. Бубела зазначав: «Дня 19 вересня 1918 р. я прибув до Львова і цього ж дня був призначений національною радою на керівника підпільного військового ревкому. Мені було поставлене конкретне завдання здійснити переворот обов'язково 1 листопада, щоб попередити польський виступ. Не дивлячись на наявність тільки 800 штиків та 30 старшин переворот здійснено. Техніку перевороту проводив я, командував січовий стрілець Вітовський...» [3, арк. 4].

Після вдалого Листопадового чину та створення Західноукраїнської Народної Республіки (ЗУНР) П. Бубела ввійшов до складу уряду, займав посаду заступника державного секретаря військових справ ЗУНР, а після Акту Злуки Західної Області Української Народної Республіки (ЗОУНР) - аж до часу переформатування уряду та встановлення диктатури Свгена Петрушевича влітку 1919 р. після відступу за р. Збруч. «Уряд відстановлено - керування перейняв диктатор Петрушевич, який в червні 1919 року заявив, що звільняє мене у відпустку, бо проти мене всі старшини», - писав П. Бубела [3, арк. 5].

Наприкінці 1919 р. йому як військовому юристу довелося взяти участь у ще одному судовому процесі, вже на стороні обвинувачення, над генералом Мироном Тарнавським, тоді командуючим Українською Галицькою Армією (УГА), який, на думку керівництва, зокрема Головного Отамана Симона Петлюри, самовільно уклав 6 листопада 1919 р. угоду про перемир'я з денікінцями. М. Тарнавський не вважав за потрібне повідомляти про свої дії С. Петлюру, оскільки вважав, що він підпорядковується лише Є. Петрушевичу [11, с. 136]. Коли С. Петлюра довідався про «самочинні», з його точки зору, дії генерала, то поставив ультимативну вимогу заарештувати й віддати під суд воєнного трибуналу генерала М. Тарнавського, полковника А. Шаманека та отамана О. Лисняка.

До складу військового трибуналу ввійшов і П. Бубела. Він взяв участь у судових засіданнях. Так, з архівних документів «судової справи про обвинувачення генерала УГА Мирона Тар- навського, полковника Альфреда Шаманека та отамана Омеляна Лисняка в невиконанні наказу штабу Головного Отамана» дізнаємося, що П. Бубела як член суду брав участь у допиті О. Лисняка 13 листопада 1919 р. [12, арк. 6]. У кінцевому підсумку військовий суд виправдав дії генерала М. Тарнавського, хоча й усунув його від керівництва армією, а новий командувач УГА генерал Осип Микитка продовжив переговори 3 денікінцями.

На початку 1920 р. командування доручило П. Бубелі разом із т. зв. «булавною сотнею» УГА спробувати взяти під контроль Одесу й утримувати місто до приходу галицьких військових частин, інтернованих в Італії. Але на початку квітня 1920 р. до Одеси ввійшли війська Червоної Армії й П. Бубелу заарештували разом з тією військовою частиною УГА, яка тоді знаходилася в Одесі. 3 іншими військовополоненими його вивезли до Харкова.

Після звільнення повернувся до Одеси. Сім'я П. Бубели (дружина Мальвіна (1899 р. н.) з грудною дитиною - сином Євгеном (1920 р. н.), іiі матір, теща Петра - Лея Туртельтауб (1866 р. н.)) фактично голодувала. Мешкав з родиною на вул. Южній, 10, кв. 7 [3, арк. 2]. В Одесі два роки працював у Губкомунвідділі в інформаційноінструкторському відділенні. Після скорочення штатів, у 1922 р., перейшов на посаду управляючого в одеське відділення товариства «Червоний Хрест» [3, арк. 5].

Після подій 1920 р. в Одесі залишалася значна кількість галичан, колишніх старшин УГА, з якими контактував П. Бубела й з якими, можливо, мав намір продовжувати визвольну боротьбу. Серед цих старшин можна згадати 3. Айвайля, Ф. Бардишівського, Ф. КюнцаВінницького, Д. Боднара, А. Музичка, І. Цьокана, Омеляна Тарнавського (сина та ад'ютанта генерала М. Тарнавського), Коника, Чайківського та ін. Як зазначав П. Бубела: «Після розгрому УНР боротьба з Радвладою не закінчилась. Еміграція, а також ті націоналістичні кола, що залишались в країні, не склали зброї, вони ії заховали і підготовляли до відповідного моменту. Українські національні кола внаслідок тих обставин, що склались після 1920 р., не погоджуючись 3 існуючим станом - поставили собі за мету - підготовку і концентрацію сил для нового виступу. До тих кіл належав і я. Вихований в суто націоналістичному дусі, загартований в національній боротьбі 3 поляками, організувавший збройний виступ проти останніх, колишній товариш державного 
секретаря у військових справах Галицько-Українського уряду, залишившись в Одесі, - я став уже своїм минулим та своїм світоглядом носієм самостійницьких ідей - «Великої незалежної України - від Кавказу по Сян», навколо якого не могли не групуватись всі ті, хто поділяв такі ідеї. Я був тим, на якого покладала надії як еміграція, гадаючи, що залишившись в УСРР, я не буду сидіти зі заложеними руками, так і націоналістичні кола тут, які бачили в мені корисну для здійснення вказаних ідей людину. Обставини, що існували протягом перших років мого перебування тут, не давали змоги зараз же розгорнути роботу. Вона обмежувалася нав'язанням знайомств та стягненням до Одеси - галичан з рештків армії, які могли становити надійний елемент для роботи, що передбачалась. I так вже у 1922 р. в Одесі знаходилися Музичка, Бардишевський, Лесюк, Ліцинський, Гузар, Копитко, Івасевич та деяка кількість (8-10 чол.) галицьких стрільців, прізвища яких, за винятком Островського, не пригадую. 3 часом до Одеси прибули Айвайль, Василишин, Мануляк, Боднар, Кюнц. Ще до цього мені було відомо, що в Балті мешкає Топущак, і що на території Балтщини $є$ ще не мало старшин та стрільців, рівно як і в інших місцевостях УСРР знаходилися більші або менші їх групи. Справа вимагала їх згрупування. Як це проходило в інших містах, мені не відомо. В Одесі не кожний, хто виринув, являвся до Червоного Хреста, де зустрічав мене i при спільній допомозі, як галичан, так і місцевих українців влаштовувався тут в Одесі. Так було і з Івасевичем, Василишиним, Мануляком. Першому допомогла К. Гус, другому один з українців, що працював у профспілці та Альвайль, третьому - ж - Альвайль за моїм почином. Розумієтся, малось на увазі, в першу чергу, забезпечити людині існування. Так склалась в Одесі група галичан. Зустрічі між галичанами були приватні. Темою розмов переважно була справа Галичини, надія на новий похід еміграції при допомозі чужоземців проти УСРР. Себто стара орієнтація відносно звільнення Галичини: «Через Київ на Львів» [3, арк. 30].

В Одесі П. Бубела нав'язав також контакти 3 О. Жуківським (колишнім воєнним міністром УНР), який прибув із Харкова у 1924 р. як представник від ЦК УПСР (Української партії соціалістів-революціонерів). Він зазначав, що з О. Жуківським зустрічався у 1924 р. та мав з ним серйозну розмову, зміст якої полягав у «політичній установці проти Радвлади, необхідності консолідації сил та підготовки їх на випадок наступу. Нас обох це об'єднувало і хоча він прямо, можливо, і не казав цього, але було зрозуміло, що з цього часу він вважав мене членом цієї організації, до якої він належав, а разом зі мною і те угрупування, яке мене оточувало [3, арк. 43]. «Вербувати мене не було потреби - розмовляли к. військовий міністр УНР і колишній товариш воєнного держсекретаря Галичини - обидва ми вважали більшовиків національними ворогами України. На його питання, як в Одесі, я відповів, що деяка кількість офіцерів уже $\epsilon$, можливо з'являться ще, та як багато поховалось. У всякому випадку $\epsilon$ та кількість, яка може служити зародком для зібрання бойових сил..» [3, арк. 212]. П. Бубела, О. Жуківський, згодом І. Цьокан утворили т. зв. «військову групу», метою якої стала підготовка збройного виступу й підтримка військової інтервенції на Півдні України.

Після арешту, на допитах, П. Бубела відзначав, що він «вважався тією силою, яка повинна була виступати безпосередньо перед і в момент діï, і приймаючи до уваги моє минуле, для мене передбачалася військова ділянка, тобто керівництво майбутнім Одеським кошем. Роль моя до моменту арешту не була такою активною, як потрібно було, так як я не мав можливості проводити відповідну роботу в тих місцях, де можна було їі проводити, за відсутності там у мене необхідного грунту. Відносно плану військових дій, то він спочатку обмежувався підготовкою повстань, а на випадок якщо б потреба в цьому відпала через близькість кордону, кадри повинні були бути пересунуті на дальшу територію, тобто передані у розпорядження інших філій. Детального плану, складеного і узгодженого, до моменту арешту не було. Не були ще готові загони, організація яких передбачалася в районах Одещини» [3, арк. 46].

Важко сказати, чи спроби організувати в Одесі рух опору радянському режиму у вигляді діяльності т. зв. «української контрреволюційної організації» та одеського відділення Української військової організації (УВО) дійсно мали місце, чи це була масштабна, добре спланована та підготовлена операція Державного політичного управління (ДПУ).

На початку 1931 р. (11 лютого) органи ДПУ затримали П. Бубелу, а 21 березня йому обрали запобіжний захід у вигляді утримання в одеському ДОПРі. Його справа розглядалася т. зв. «судовою трійкою» одеського відділення ДПУ у складі уповноважених Шерстова, Толкачова та зам. начальника одеського оперативного сектора ДПУ Галицького. 
Слідча справа П. Бубели за номером 6781 нараховує понад 200 сторінок і складається з протоколів допитів П. Бубели, показів О. Тарнавського, І. Штефана, А. Дідуника, протоколу очної ставки між П. Бубелою та І. Штефаном, виписок із протоколів допитів Макарушки, Яворського, звинувачувального вироку, виписки 3 протоколу засідання судової трійки при колегії ДПУ УСРР та інших документів.

У постанові про початок слідства, обрання запобіжного заходу та пред'явлення обвинувачення зазначалося таке: «м. Одеса, 21 березня 1931 р., я ст. уповноважений II гр. таємного відділу Одеського сектору ДПУ УСРР Шерстов, розглянувши матеріали про злочинну діяльність г-на Бубело Петра Івановича, яка виявилася у приналежності до Української контрреволюційної організації, та, вбачаючи в означених діях наявність ознак злочину, передбачених ст. ст. 54 II КК УСРР,

ПОСТАНОВИВ:

1. На підставі ст. ст. 93 п. 2 і 103 КПК дану справу взяти до свого виробництва і розпочати попередне слідство.

2. На підставі ст. 126 та, керуючись ст. 127 КПК, притягнути г-на Бубело Петра Івановича по даній справі у якості звинувачуваного, висунув йому обвинувачення за ст. ст. 54 II КК УСРР.

3. На підставі ст. ст. 142 і 144 та, керуючись ст. ст. 145 і 156 КПК, заходом припинення способів ухилення від суду та слідства стосовно обвинуваченого Бубело обрати утримання під вартою [3, арк. 6].

Копії даної постанови передати Одеському прокурору і начальнику місця позбавлення волі.

Ст. уповноважений II гр. ТО

Погоджуюсь Нач. Таєм. Відділ.

Затверджую Нач. сектора» [3, арк. 6/2 зв.].

Слідство у справі П. Бубели тривало майже рік 321 березня 1931 р. до 5 березня 1932 р. Під час допитів П. Бубело на відміну від інших учасників процесу поводив себе гідно, що, наприклад, засвідчує протокол очної ставки від 16 травня 1931 р. між ним та І. Штефаном (колишнім міністром фінансів Центральної Ради):

«Протокол очної ставки між Бубело і Штефаном $16 / \mathrm{V}-31 \mathrm{p}$.

Штефан:

Я був членом к-р української організації і представником центру в Одесі. Гр. Бубело також являвся членом нашої організації і був керівником військової галузі організації в Одесі. Бубело був пов'язаний по цій лінії сам безпосередньо із центром в особі спочатку Жуковського, а після

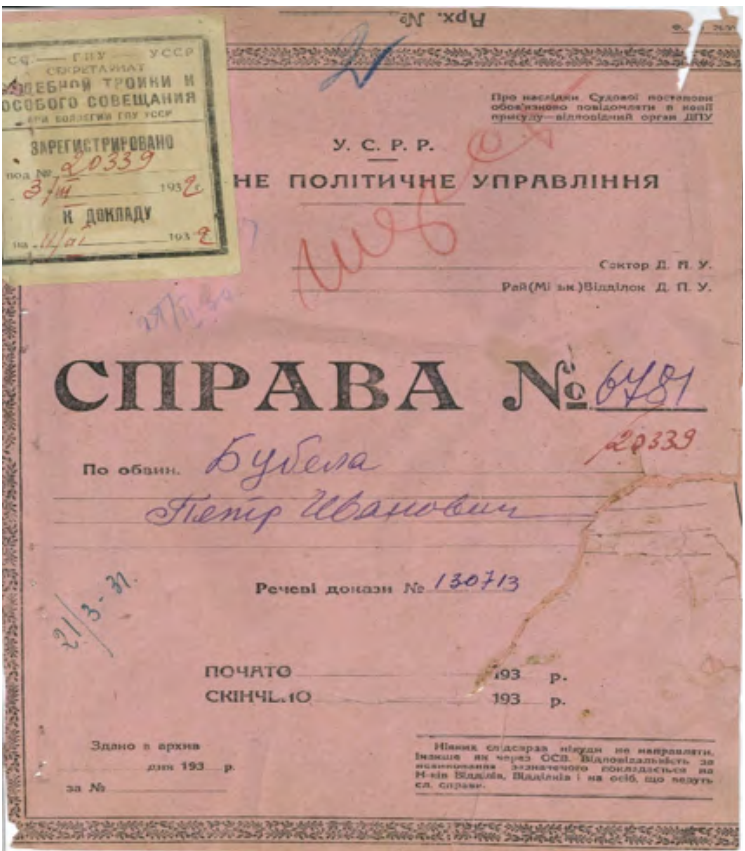

Рис. 1. Слідча справа П. Бубели. Одеса. 1931 р. Джерело: ДАОО, ф. 8065, оп. 2, спр. 7792, арк. 1

його смерті - 3 Коссаком. Окрім того, Бубело був також пов'язаний з одеським керівництвом.

Бубело:

Я не заперечував можливості призначення мене на вказану Штефаном роль керівника військової галузі в організації. Зараз не пригадую, чи мав я 3 цього приводу прямі вказівки, однак свій зв'язок з Коссаком безпосередньо чи посередньо через третіх осіб я заперечую.

Штефан:

Я, спільно з гр. Бубело та ін. особами, що були керівниками одеської організації, неодноразово збиралися та обговорювали питання, що стосувалися діяльності організації.

Бубело:

Я ніде разом зі Штефаном у місці, де б обговорювалися питання організації, не зустрічався. Я взагалі зі Штефаном, я пам'ятаю, зустрічався раз тільки в Українбанку в 1922 p.

Штефан:

У другій половині 1930 р. у нас була нарада ще 3 низкою членів нашої організації у приміщенні Червоного Хреста, де обговорювалося питання необхідності виконання директиви всеукраїнського центру про складення оперативного плану. Робота ця була доручена Бубело і Цьокану з тим, щоб вони зв'язалися 3 цього питання 3 центром в особі військового керівництва. Нарада ця була у приміщенні на розі Дерибасівської і Пушкінської. 
Бубело:

Такої наради ніколи не було» [3, арк. 94].

Так званий процес над П. Бубелою завершився винесенням йому звинувачувального вироку, в якому, зокрема, зазначалося, що «Одеським Оперативним Сектором ДПУ УСРР весною 1931 року розкрито і ліквідовано Одеський філіал української контрреволюційної організації, що ставила своєю кінцевою метою повалення Радвлади шляхом збройного повстання і відновлення капіталістичних відносин на Україні.

Організація у своїй практичній к. р. діяльності займалась створенням к. р. кадрів, в основному 3 середовища українського шовіністичного к. p. елементу міста і села, проведенням к. р. шовіністичної агітації, з захопленням командних висот в основних культурних і кооперативних закладах як у місті, так і на селі, одночасно проводячи шкідницьку діяльність на тих ділянках радянської роботи, де знаходилися її члени.

Організація поділялася на окремі самостійні лінії - галицьку, академічно-шкільну і кооперативну.

У своїй роботі Одеський філіал української к. p. організації був пов'язаний з центрами у Києві та Харкові, отримуючи необхідні директиви і періодично інформуючи їх про свою діяльність.

Для своєї к. p. діяльності академічношкільна лінія організації всіляко використовувала легально оформленні українські культурні заклади і організації міста Одеси - Укр. Бібліографічне Тов-во, Наукову Бібліотеку, ВУЗ'и та ін., де під прикриттям цієї організації концентрувалися українські антирадянські сили. Галицька військова організація УВО ставила своїм завданням оперативну підготовку збройного повстання i комплектування сил комскладом. На основі

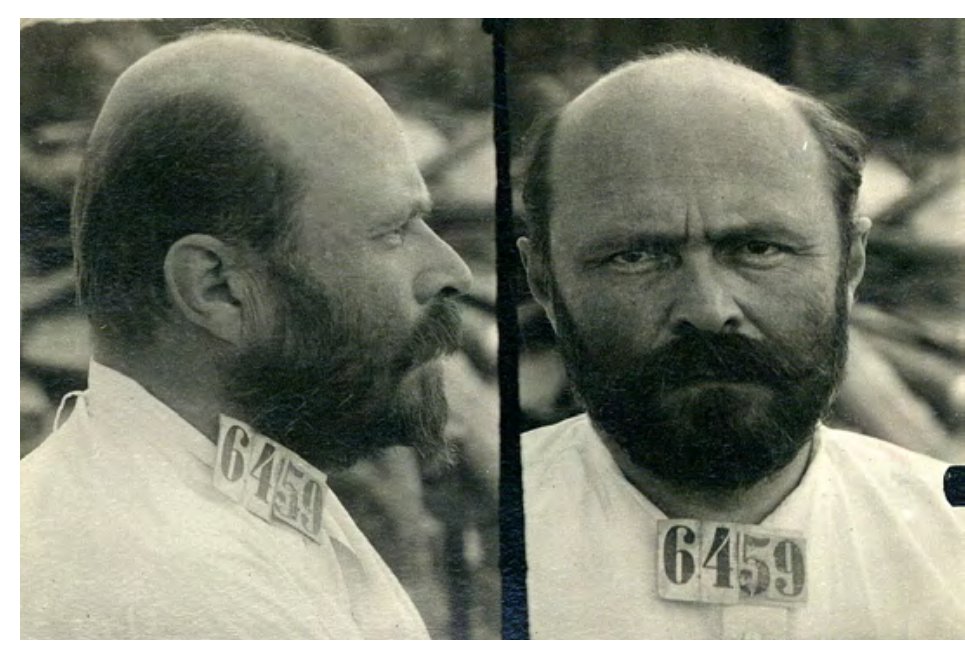

Рис. 2. П. Бубела в ув'язненні. Одеса. ДОПР. 1931 р. Джерело: ДАОО, ф. 8065, оп. 2, спр. 7792, арк. 216 слідчих матеріалів по даній справі арештовано керівника Одеської організації УВО - Бубело Петра Івановича» [3, арк. 211].

П. Бубелу звинувачували у приналежності до керівництва «української контрреволюційної організації», одеської філії УВО, в підготовці збройного повстання, для чого він нібито організував групу із 30-ти колишніх галицьких офіцерів, зробив план розподілу їх на командні пости для організації повстанських загонів [3, арк. 213]. Окрім того, П. Бубелі закидалося й те, що він, будучи з 1925 р. «таємним співробітником Одеського Окрвідділу ДПУ, дезінформував останній, даючи свідчення про радянське налаштування членів організації».

Акт звинувачення завершувався таким вироком: «Обвинувачуваний Бубело винним себе визнав. Вважаючи встановленою приналежність обвинувачуваного Бубело до укр. к. р. організації, яка поставила своїм завданням повалення Радвлади і заміну іiї буржуазною республікою, що передбачене ст. 54-11 КК УСРР,

ПОСТАНОВИВ:

Слідсправу за № 6781 за звинуваченням Бубело Петра Івановича, 1889 р. народж. 3 с. Лисиничі (Галичина), к. товариша воєнного міністра Гал. УНР, з вищою освітою, служив Управсправами Одеської філії Чр. Хреста, не судимого, б/п, одруженого, чл. союзу «Медсанпраця», українця, на воїнському обліку не стоїть - направити на розгляд судтрійки при Колегії ДПУ УСРР 3 ходатайством ув'язнити обвинуваченого Бубело до концтабору терміном на вісім (8) років» [3, арк. 214].

У березні 1932 р. справу П. Бубели відправили на розгляд судової трійки при колегії ДПУ УСРР, яка на своєму засіданні, що відбулося 5 березня, вирішила таке: «Слухали: справу № 6781/20339 Одеського облвідділу ДПУ по зв. гр. Бубело Петра Івановича, 42 р. по ст. 54-11 КК.

Постановили: Бубело Петра Івановича ув'язнити в концтабір терміном на три роки, рахуючи термін з 21. III. 31 року. Справу здати в архів» [3, арк. 215].

У 1989 р., в часи горбачовської «перебудови», заступник прокурора Одеської області, державний радник юстиції В. Дацюк, помічник прокурора Одеської області, старший радник юстиції 3. Садикова, начальник слідчого відділу по Одеській області, радник юстиції І. Левченко 23 травня 1989 р. прийняли рішення вже посмертно скасувати вирок, винесений 
П. Бубелі, й вирішили, що він підпадає під дію ст. 1. Указу Президії Верховної Ради СРСР від 16 січня 1989 р. «Про додаткові заходи з відновлення справедливості у відношенні жертв репресій, що мали місце у 30-40-х і на початку 50-х років» [3, арк. 220].

Висновки і перспективи подальших досліджень у цьому напрямі. Таким чином, аж у часи «перебудови», 1989 р., необгрунтовані звинувачення проти П. Бубели, висунуті на закритому судовому процесі 1931 р., було знято. Його реабілітація свідчить, що всі обвинувачення в нібито участі в «українській контрреволюційній організації», Українській Військовій Організації (УВО) тощо фабрикувалися органами безпеки ДПУ й стали складовою частиною сталінського курсу, спрямованого на посилення репресій проти українців напередодні масового їх винищення - геноциду шляхом організації штучного голодомору 1932-1933 pp.

За свою свідомо проукраїнську, націоналістичну позицію, особливо ним виявлену на судовому процесі 1931 р., П. Бубела заплатив життям. У 2005 р. мешканці с. Лисиничі увіковічнили пам'ять земляка, відкривши йому пам'ятник. Діяльність та життєвий шлях П. Бубели ще мало вивчені, потребують подальших грунтовних наукових досліджень.

\section{ЛІТЕРАТУРА:}

1. Боберський I. Щоденник 1918-1919 pp. Київ : КМ Академія, 2003. 260 с.

2. Державний архів Львівської області. Ф. 26. Оп. 15. Спр. 126.

3. Державний архів Одеської області. Ф. 8065. Оп. 2. Спр. 7792.

4. Критика уживання русинами польської мови обидою релігії (3 судової салі). Діло. Львів, 1911. 4 падолиста. Ч. 246.

5. Курилишин К. Часопис «Діло» (Львів, 18801939 рр.) : матеріали до біобібліографістики ; НАН України, Львівська національна наукова бібліотека України ім. В. Стефаника. Дрогобич : Коло, 2020. T. 6: 1910-1914. $696 \mathrm{c.}$

6. Кучерук В. Українська Галицька Армія: довідник ; Львівський історичний музей. Київ : Київська нотна фабрика, 2010. 448 с.
7. Лаба В. Історія села Лисиничі від найдавніших часів до 1939 року. Львів, 2004. 84 с.

8. Литвин М., Науменко К. Історія галицького стрілецтва. Вид. 2-ге. Львів : Каменяр, 1991. 200 с.

9. Литвин М. Історія ЗУНР. Львів : Видавнича фірма ОЛІР, 1995. 362 c.

10. Палажій Г. Хто насправді організував Листопадовий Чин? URL: http: //h.ua/story/20660

11. Тарнавський М. Спогади. Львів : Червона Калина, 2008. 168 с.

12. Центральний державний архів України в м. Львові. Ф. 581. Оп. 1. Спр. 149.

\section{REFERENCES:}

1. Boberskyj,I.,(2003), Schodennyk 1918-1919 rr., Kyiv, КМ Акаdеміjа. 260 p. [in Ukrainian].

2. Derzavny archv Lvivskoi oblasti, DALO, f. 26, op. 15 , spr. 126.

3. Derzavny archv Odeskoi oblasti, f. 8065, op. 2, spr. 7792 .

4. Krytka uzyvannia rusynamy polskoi movy obydoju religii (Z sudovoi sali)? Dilo? Lviv, 1911, 4 padolysta, Ch. 246. [in Ukrainian].

5. Kurylychyn, K., (2020), Chasopys Dilo (Lviv, 1880-1939 rr.): materialy do biobibliografistyky / NAN Ukrainy, Lvivska natsionalna biblioteka Ukrainy im. V. Stefanyka, Drogobych, Kolo, t. 6.(1910-1914 rr.), 696 s. [in Ukrainian].

6. Kucheruk, V., (2010), Ukrainska Galytska Armia, dovidnyk / Lvivskyj istorychnyj muzej, Kyiv, Kyivska notna fabryka, 448 p. [in Ukrainian].

7. Laba, V., (2004), Istoria sela Lysynychi vid najdavnishyh chasiv do 1939 roku, Lviv, 2004, 84 p. [in Ukrainian].

8. Lytvyn, M., Naumenko K., (1991), Istoria galytskogo strilectva, vyd. 2-e, Lviv, Kameniar, 1991, 200 p. [in Ukrainian].

9. Lytvyn, M., Istoria ZUNR, Lviv, Vydavnycha firma Olir, 1995, 362 p. [in Ukrainian].

10. Palazij G. Hto naspravdi organizuvav Lystopadovyj Chyn? URL: http: // h.ua/story/20660. [in Ukrainian].

11. Tarnavskyj, M., (2008), Spogady, Lviv, Chervona kalyna, 168 p. [in Ukrainian].

12. Centralnyj derzavnyj arhiv Ukrainy u m. Lvovi, CDIAUL, f. 581, op. 1, spr. 149.

Стаття надійшла до редакиії 03.09.2021 